\title{
Efficiency of fungicides with the addition of multicomponent bioadjuvant in the protection of winter oilseed rape against pathogens
}

\section{Skuteczność działania fungicydów z dodatkiem wielokomponentowego bioadiuwantu w ochronie rzepaku ozimego przed patogenami}

\author{
Romuald Gwiazdowski $^{1 *}$, Roman Kierzek ${ }^{1}$, Krzysztof Kubiak $^{1}$, Henryk Ratajkiewicz ${ }^{2}$
}

\begin{abstract}
Summary
The paper presents the results of field and laboratory experiments on the new, multicomponent bioadjuvant - Stradale. This product was used in a tank mixture with two fungicides: Caryx $240 \mathrm{SL}$ (metconazole and mepiquate chloride) and Tebu $250 \mathrm{EW}$ (tebuconazole) to protect winter oilseed rape against pathogens. The action of adjuvant was probably related to a high content of gum arabic and natural surfactants (alkyl polyglycosides and glycolipids). The addition of bioadjuvant affected positively biological activity of fungicides in reducing the occurrence of grey mould (Botrytis cinerea) and alternaria black molds (Alternaria spp.) on the winter oilseed rape leaves.
\end{abstract}

Key words: bioadjuvant; oilseed rape; diseases; fungicides

\section{Streszczenie}

W pracy zaprezentowano wyniki badań polowych i laboratoryjnych nad nowym, wieloskładnikowym bioadiuwantem - Stradale. Produkt użyto w mieszaninie z dwoma fungicydami: Caryx $240 \mathrm{SL}$ (metkonazol i chlorek mepikwatu) i Tebu 250 EW (tebukonazol) do ochrony rzepaku ozimego przed patogenami. Działanie wspomagające bioadiuwantu prawdopodobnie związane było z zawartością gumy arabskiej oraz naturalnych związków o cechach surfaktantu (alkilopoliglukozydów i glikolipidów). Dodatek bioadiuwantu wpłynął korzystnie na działanie biologiczne fungicydów w ograniczaniu występowania szarej pleśni (Botrytis cinerea) i czerni krzyżowych (Alternaria spp.) na liściach rzepaku.

Słowa kluczowe: bioadiuwant; rzepak; choroby; fungicydy

\footnotetext{
${ }^{1}$ Instytut Ochrony Roślin - Państwowy Instytut Badawczy

Władysława Węgorka 20, 60-318 Poznań

${ }^{2}$ Uniwersytet Przyrodniczy w Poznaniu

Wojska Polskiego 28, 60-637 Poznań

*corresponding author: r.gwiazdowski@iorpib.poznan.pl
} 


\section{Wstęp / Introduction}

Choroby roślin rolniczych stanowią poważny problem zarówno pod względem obniżenia opłacalności produkcji, jak i pozyskiwania żywności o dobrej jakości. Chemiczna ochrona rzepaku przed patogenami ukierunkowana jest na minimalizowanie nasilenia objawów chorób przez zabiegi z użyciem odpowiednich fungicydów (Mrówczyński i Pruszyński 2008). Efektywność działania środków grzybobójczych można znacząco poprawić poprzez zwiększenie ich wnikania i pokrycia chronionych powierzchni roślin. Szansę poprawy skuteczności działania fungicydów upatruje się coraz częściej w adiuwantach o cechach aktywujących i modyfikujących (Korbas i wsp. 2016; Sawinska i wsp. 2016). Dość powszechnie wykorzystywane są surfaktanty syntetyczne. Mimo wielu zalet, mogą być toksyczne dla organizmów i podlegać zbyt wolnej biodegradacji. Stąd też, coraz większe zainteresowanie budzą środki powierzchniowo czynne z grupy biosurfaktantów, które uważane są za mniej toksyczne i bardziej ekologiczne. Mają one duży potencjał i mogą być wykorzystane w przemyśle farmaceutycznym, kosmetycznym i produkcji rolniczej, między innymi do wspomagania zabiegów przeciwko patogenom i szkodnikom roślin lub do zwiększenia biodostępności substancji odżywczych. Liczne doniesienia wskazują, że biosurfaktanty glikolipidowe stymulują odporność roślin i ograniczają infekcje powodowane przez grzyby (Zhang i wsp. 2011; Sha i wsp. 2012; Sachdev i Cameotra 2013). Współczesne adiuwanty to zwykle produkty wielokomponentowe i wielofunkcyjne. Guma arabska może być rozpatrywana jako składnik preparatu wspomagającego. Jest ona rozpuszczalnym w wodzie polimerem pochodzenia naturalnego $\mathrm{i}$ od lat znajduje zastosowanie $\mathrm{w}$ procesie mikrokapsułowania różnych substancji, w tym środków ochrony roślin (Kurtz i Hassett 1988; Eratte i wsp. 2015). Roztwór koloidowy naturalnej gumy może promować utworzenie filmu na docelowej powierzchni i przeciwdziałać rozwojowi mikroorganizmów w produktach spożywczych (Chappell 1995). Zaletami biosurfaktantów są niewątpliwie wysoka aktywność powierzchniowa i międzyfazowa, tolerancja na zmiany $\mathrm{pH}$ w szerokim zakresie, większa biodegradowalność, niska toksyczność oraz możliwość produkcji z surowców odpadowych czy też odnawialnych źródeł węgla (Scott i Jones 2000; Singh i wsp. 2007; Lima i wsp. 2011). Biorąc pod uwagę cenne właściwości adiuwantów na bazie naturalnych biosurfaktantów i innych biodegradowalnych związków można przypuszczać, iż W przyszłości $\mathrm{z}$ powodzeniem będą one zastępować „wspomagacze” syntetyczne.

Celem badań była ocena skuteczności działania fungicydów z grupy triazoli (metkonazolu i tebukonazolu) $\mathrm{z}$ dodatkiem nowego, wieloskładnikowego bioadiuwantu w ograniczaniu występowania objawów chorób rzepaku ozimego powodowanych przez grzyby.

\section{Materiały i metody / Materials and methods}

\section{Doświadczenia laboratoryjne}

Napięcie powierzchniowe zmierzono metodą odrywania pierścienia. Doświadczenia wykonano w 4 powtórzeniach. Powierzchnię rozlania kropli o objętości $2 \mu 1$ zmierzono na parafilmie (Bemis) na podstawie zdjęć wykonanych pod mikroskopem Discovery v. 12 używając zintegrowanego oprogramowania AxioVision v. 4.9. Doświadczenia wykonano w 4 powtórzeniach, wymiarując w każdym po 4 krople.

\section{Doświadczenia polowe}

Dwuletnie doświadczenia polowe wykonano w sezonach 2013/2014 i 2014/2015 na terenie Polowej Stacji Doświadczalnej w Winnej Górze należącej do Instytutu Ochrony Roślin - Państwowego Instytutu Badawczego (IOR - PIB) w Poznaniu. Badania przeprowadzono w układzie bloków losowanych w 4 powtórzeniach. Do zabiegów wykorzystano dwa handlowe fungicydy: Caryx 240 SL (producent - BASF SE, substancja czynna: chlorek mepikwatu - 210 g/l + metkonazol - 30 g/l) oraz Tebu 250 EW (producent - Helm AG, substancja czynna: tebukonazol - $250 \mathrm{~g} / \mathrm{l}) \mathrm{w}$ dawkach zalecanych i obniżonych do $75 \%$ dawki rekomendowanej. Do fungicydów dodawano wielokomponentowy bioadiuwant Stradale w formulacji proszku, który zawiera 4 składniki (producent - Agricis Smart Science, skład: guma arabska - 77\%, alkilopoliglukozydy - 8\%, glikolipidy - 7\% i ko-formulanty $-8 \%$ ). Schemat doświadczenia oraz badane dawki przedstawiono w tabeli 1 . Zabiegi opryskiwania wykonano

Tabela 1. Schemat doświadczenia

Table 1. The experimental design

\begin{tabular}{l|c|c}
\multicolumn{1}{c|}{$\begin{array}{c}\text { Kombinacja } \\
\text { Treatment }\end{array}$} & $\begin{array}{c}\text { Dawka na 1 ha } \\
\text { Dose per 1 ha }\end{array}$ & $\begin{array}{c}\text { Procent dawki zalecanej } \\
\text { Percent of recommended dose }\end{array}$ \\
\hline Kontrola - Untreated & - & - \\
\hline Caryx 240 SL & $1,0 \mathrm{l}$ & $100 \%$ \\
\hline Caryx 240 SL + bioadiuwant* & $1,0 \mathrm{l}+100 \mathrm{~g}$ & $100 \%+$ bioadiuwant \\
\hline Caryx 240 SL + bioadiuwant & $0,75 \mathrm{l}+100 \mathrm{~g}$ & $75 \%+$ bioaduwant \\
\hline Tebu 250 EW & $1,0 \mathrm{l}$ & $100 \%$ \\
\hline Tebu 250 EW + bioadiuwant & $1,0 \mathrm{l}+100 \mathrm{~g}$ & $100 \%+$ bioadiuwant \\
\hline Tebu 250 EW + bioadiuwant & $0,75 \mathrm{l}+100 \mathrm{~g}$ & $75 \%+$ bioadiuwant \\
\hline
\end{tabular}

* - bioadiuwant wielokomponentowy Stradale: guma arabska - 77\%, związek niejonowy alkilopoliglukozyd - 8\%, glikolipidy - 7\% i ko-formulanty - 8\%

* - multicomponent bioadjuvant Stradale: gum arabic - 77\%, non ionic compound alkyl polyglycoside - 8\%, glycolipids - 7\% and co-formulants - 8\% 
w 2014 roku w fazie pąkowania (BBCH 50), a w 2015 roku w fazie wydłużania pędu głównego (BBCH 33) przy użyciu poletkowego opryskiwacza plecakowego z wykorzystaniem rozpylaczy niskoznoszeniowych AIXR 11003 i stałej ilości cieczy użytkowej 200 1/ha.

Rzepak ozimy odmiany Bogart uprawiano w monokulturze na glebie o klasie bonitacyjnej IIIa i pH 5,8. Rzepak wysiewano w ostatnich dniach sierpnia w ilości 4,4 kg/ha w 2013 roku i 3,7 kg/ha w 2014 roku. Podczas uprawy stosowano standardowe zabiegi agrotechniczne i ochronę chemiczną przed agrofagami zgodną z zaleceniami IOR - PIB. Na poletkach doświadczalnych nie stosowano dodatkowej ochrony fungicydowej, poza ujętą w schemacie doświadczenia.

Skuteczność działania fungicydów w ochronie rzepaku ozimego przed patogenami oceniano szacując średni procent porażonej powierzchni liści na 25 losowo wybranych roślinach, na każdym poletku. Ocenę zdrowotności roślin wykonano $\mathrm{w}$ fazie opadania płatków kwiatowych (BBCH 67). W celu określenia efektywności działania badanych środków wykonano pomiary plonu i masy 1000 nasion (MTN).

Wykonano także wizualną ocenę wrażliwości rzepaku ozimego (fitotoksyczność) na zastosowane środki, biorąc pod uwagę: kondycję roślin, ich wielkość i pokrój, zmianę barwy, deformacje organów i nekrozy na liściach.

\section{Statystyka}

Analizy statystyczne uzyskanych wyników wykonano w programie STATISTICA v. 13. W celu porównania wartości średnich przeprowadzono jednoczynnikową analizę wariancji (ANOVA), a hipotezy szczegółowe weryfikowano przy użyciu testu Fishera (NIR) na poziomie istotności $\alpha=0,05$.

\section{Wyniki i dyskusja / Results and discussion}

Podstawową i najczęściej docenianą właściwością związków powierzchniowo czynnych z grupy surfaktantów jest ich zdolność do obniżania napięcia powierzchniowego i międzyfazowego (Singh i wsp. 2007). Poszczególne składniki badanego bioadiuwantu Stradale wykazują różne właściwości i oddziaływanie. Naturalna guma arabska ma właściwości sklejające. Niejonowy, cukrowy alkilopoliglukozyd otrzymany $\mathrm{z}$ wyciągu $\mathrm{z}$ roślin (słoma zbóż) posiada cechy zwilżające, humektacyjne i zwiększające przenikanie. Z kolei glikolipidy produkowane przez mikroorganizmy (Candida spp.) mają cechy typowego surfaktantu pochodzenia mikrobiologicznego (Paraszkiewicz i Długoński 2003). W odróżnieniu od klasycznych związków powierzchniowo-czynnych surfaktanty z ugrupowaniem cukrowym (np. glikolipidy) składają się $\mathrm{z}$ różnych rodzajów cukrów połączonych $\mathrm{z}$ kwasami tłuszczowymi wiązaniami glikozydowymi (Pattanathu i Gakpe 2008). Związki te wykazują powinowactwo zarówno do cieczy polarnych, jak i niepolarnych, czego efektem jest zdolność do obniżenia napięcia powierzchniowego oraz napięcia na granicy faz (woda/powietrze i woda/olej).

Na podstawie uzyskanych wyników badań z dwoma fungicydami (różne dawki) i bioadiuwantem stwierdzono, że wartość napięcia powierzchniowego dla sporządzonych cieczy użytkowych wahała się pomiędzy 28,66-31,37 mN/m (tab. 2). Napięcie powierzchniowe było najniższe w cieczy użytkowej z samym bioadiuwantem Stradale $(27,4 \mathrm{mN} / \mathrm{m})$, który nie stanowił obiektu doświadczalnego $\mathrm{w}$ badaniach polowych. Mimo, że napięcie cieczy użytkowej zawierającej fungicyd było większe, to wyniosło, co najwyżej $31,1 \mathrm{mN} / \mathrm{m}$. Pod wpływem adiuwantu obserwowano spadek napięcia powierzchniowego cieczy użytkowej, jednak w większości przypadków nie był on statystycznie istotny. Powierzchnia rozlania kropli cieczy użytkowej zawierającej sam bioadiuwant Stradale nie różniła się od powierzchni rozlania cieczy zawierającej bioadiuwant i fungicydy. Dla ocenianych obiektów doświadczalnych rozlanie było 3,1-3,5 razy większe w porównaniu do samej wody.

Różnice w fazie rozwojowej rzepaku, w której wykonano zabieg opryskiwania spowodowane były niskimi temperaturami $\mathrm{w}$ okresie wiosny 2014. Po wzroście temperatur, rośliny rzepaku bezpośrednio po fazie rozety osiągnęły fazę pąkowania. W okresie

Tabela 2. Statyczne napięcie powierzchniowe i powierzchnia rozlania kropli cieczy użytkowej o objętości $2 \mu 1$ na parafilmie Table 2. Static surface tension and surface area of $2 \mu \mathrm{l}$ droplet spill on the wax surface (Parafilm)

\begin{tabular}{l|c|c|c}
\hline \multicolumn{1}{c|}{$\begin{array}{c}\text { Kombinacja } \\
\text { Treatment }\end{array}$} & $\begin{array}{c}\text { Dawka na 1 ha } \\
\text { Dose per } 1 \mathrm{ha}\end{array}$ & $\begin{array}{c}\text { Statyczne napięcie powierzchniowe } \\
\text { Static surface tension } \\
{[\mathrm{mN} / \mathrm{m}]}\end{array}$ & $\begin{array}{c}\text { Powierzchnia rozlania kropli } \\
\text { Spillage surface } \\
{\left[\mathrm{mm}^{2}\right]}\end{array}$ \\
\hline Kontrola (woda) - Untreated (water) & - & $72,45 \mathrm{e}$ & $2,30 \mathrm{a}$ \\
\hline Caryx 240 SL & $1,0 \mathrm{l}$ & $31,11 \mathrm{~cd}$ & $8,12 \mathrm{~d}$ \\
\hline Caryx 240 SL + bioadiuwant & $1,0 \mathrm{l}+100 \mathrm{~g}$ & $30,37 \mathrm{c}$ & $8,39 \mathrm{~d}$ \\
\hline Caryx 240 SL + bioadiuwant & $0,75 \mathrm{l}+100 \mathrm{~g}$ & $28,66 \mathrm{~b}$ & $7,93 \mathrm{~cd}$ \\
\hline Tebu 250 EW & $1,0 \mathrm{l}$ & $31,37 \mathrm{~d}$ & $7,16 \mathrm{~b}$ \\
\hline Tebu 250 EW + bioadiuwant & $1,0 \mathrm{l}+100 \mathrm{~g}$ & $31,05 \mathrm{~cd}$ & $7,34 \mathrm{bc}$ \\
\hline Tebu 250 EW + bioadiuwant & $0,75 \mathrm{l}+100 \mathrm{~g}$ & $30,55 \mathrm{~cd}$ & $7,38 \mathrm{bc}$ \\
\hline Bioadiuwant - Bioadjuvant & $100 \mathrm{~g}$ & $27,40 \mathrm{a}$ & $8,00 \mathrm{~cd}$ \\
\hline
\end{tabular}

bioadiuwant - bioadjuvant

Wartości średnie oznaczone tą samą literą nie różnią się istotnie

Means followed by the same letter are not significantly different 
Tabela 3. Porażenie liści rzepaku przez Botrytis cinerea i skuteczność działania fungicydów

Table 3. Leaf infection by Botrytis cinerea and efficacy of fungicides in winter oilseed rape

Kombinacja (dawka na 1 ha)

Treatment (dose per 1 ha)

\begin{tabular}{|c|c|c|c}
\hline \multicolumn{2}{|c|}{2014} & \multicolumn{2}{c}{2015} \\
\hline $\begin{array}{c}\text { porażona } \\
\text { powierzchnia } \\
\text { liścia } \\
\begin{array}{c}\text { infected leaf area } \\
{[\%]}\end{array}\end{array}$ & $\begin{array}{c}\text { skuteczność } \\
\text { działania } \\
\text { efficacy } \\
{[\%]}\end{array}$ & $\begin{array}{c}\text { porażona } \\
\text { powierzchnia } \\
\text { liścia } \\
\text { infected leaf area } \\
{[\%]}\end{array}$ & $\begin{array}{c}\text { skuteczność } \\
\text { działania } \\
\text { efficacy } \\
{[\%]}\end{array}$ \\
\hline $50,00 \mathrm{c}$ & - & $10,00 \mathrm{~d}$ & - \\
\hline $15,00 \mathrm{ab}$ & 70 & $2,50 \mathrm{bc}$ & 75 \\
\hline $7,50 \mathrm{a}$ & 85 & $1,50 \mathrm{ab}$ & 85 \\
\hline $13,75 \mathrm{ab}$ & 73 & $2,13 \mathrm{abc}$ & 79 \\
\hline $15,63 \mathrm{~b}$ & 69 & $2,25 \mathrm{bc}$ & 78 \\
\hline $10,63 \mathrm{ab}$ & 79 & $1,00 \mathrm{a}$ & 90 \\
\hline $17,50 \mathrm{~b}$ & 65 & $3,13 \mathrm{c}$ & 69 \\
\hline
\end{tabular}

bioadiuwant - bioadjuvant

Wartości średnie oznaczone tą samą litera nie różnią się istotnie

Means followed by the same letter are not significantly different

Tabela 4. Porażenie liści rzepaku przez Alternaria spp. i skuteczność działania fungicydów

Table 4. Leaf infection by Alternaria spp. and efficacy of fungicides in winter oilseed rape

\begin{tabular}{|c|c|c|c|c|}
\hline \multirow[b]{2}{*}{$\begin{array}{l}\text { Kombinacja (dawka na } 1 \text { ha) } \\
\text { Treatment (dose per } 1 \text { ha) }\end{array}$} & \multicolumn{2}{|c|}{2014} & \multicolumn{2}{|c|}{2015} \\
\hline & $\begin{array}{c}\text { porażona } \\
\text { powierzchnia } \\
\text { liścia } \\
\text { infected leaf area } \\
{[\%]}\end{array}$ & $\begin{array}{c}\text { skuteczność } \\
\text { działania } \\
\text { efficacy } \\
{[\%]}\end{array}$ & $\begin{array}{c}\text { porażona } \\
\text { powierzchnia } \\
\text { liścia } \\
\text { infected leaf area } \\
{[\%]}\end{array}$ & $\begin{array}{c}\text { skuteczność } \\
\text { działania } \\
\text { efficacy } \\
{[\%]}\end{array}$ \\
\hline Kontrola - Untreated & $35,00 \mathrm{~d}$ & - & $5,00 \mathrm{~d}$ & - \\
\hline Caryx 240 SL (1,0 l) & $10,00 \mathrm{abc}$ & 71 & $1,38 \mathrm{bc}$ & 73 \\
\hline Caryx 240 SL (1,0 l) + bioadiuwant (100 g) & 5,13 a & 85 & $0,88 \mathrm{ab}$ & 83 \\
\hline Caryx 240 SL (0,75 l) + bioadiuwant (100 g) & $9,38 \mathrm{abc}$ & 73 & 1,25 bc & 75 \\
\hline Tebu 250 EW $(1,0$ l) & $11,25 \mathrm{c}$ & 68 & $1,88 \mathrm{c}$ & 63 \\
\hline Tebu 250 EW (1,0 l) + bioadiuwant (100 g) & $5,88 \mathrm{ab}$ & 83 & $0,50 \mathrm{a}$ & 90 \\
\hline Tebu 250 EW (0,75 l) + bioadiuwant (100 g) & $10,63 \mathrm{bc}$ & 70 & $1,75 \mathrm{c}$ & 65 \\
\hline
\end{tabular}

bioadiuwant - bioadjuvant

Wartości średnie oznaczone tą samą literą nie różnią się istotnie

Means followed by the same letter are not significantly different

prowadzenia badań na roślinach rzepaku ozimego stwierdzono szarą pleśń i czerń krzyżowych. Zastosowanie fungicydów zarówno z dodatkiem, jak i bez dodatku bioadiuwantu istotnie ograniczało wystąpienie chorób. W 2015 roku bioadiuwant dodany do pełnej dawki (1,0 1/ha) Tebu 250 EW istotnie zwiększył skuteczność jego działania. $\mathrm{W}$ pozostałych przypadkach dodatek adiuwantu do fungicydów w pełnej dawce powodował zwiększenie skuteczności, ale różnice $\mathrm{w}$ porównaniu do obiektów, gdzie go nie stosowano były statystycznie nieistotne. Natomiast dodatek adiuwantu do fungicydu w dawce obniżonej $(0,75$ 1/ha $-75 \%$ dawki pełnej) powodował, że skuteczność ograniczenia nasilenia chorób była na poziomie skuteczności fungicydu zastosowanego w dawce pełnej bez dodatku wielokomponentowego bioadiuwantu (tab. 3, 4).
Podczas przeprowadzonych ocen nie stwierdzono negatywnego wpływu badanych środków (fitotosyczność), zarówno z dodatkiem, jak i bez dodatku bioadiuwantu, na rośliny rzepaku ozimego. Nie zaobserwowano istotnego wpływu badanych środków na MTN. W 2014 roku stwierdzono, że w obiektach Caryx 240 SL (1,0 1/ha) + bioadiuwant (100 g/ha), Tebu $250 \mathrm{EW} \mathrm{(1,0} \mathrm{1/ha)} \mathrm{i} \mathrm{Tebu}$ 250 EW (1,0 1/ha) + bioadiuwant (100 g/ha) plon był istotnie wyższy o 14-16\% w porównaniu do obiektu kontrolnego. W 2015 roku istotnie wyższy plon w porównaniu do kontroli stwierdzono w obiekcie Caryx 240 SL (1,0 l/ha) (tab. 5).

Badane fungicydy oparte na związkach $\mathrm{z}$ grupy triazoli stosowane pojedynczo oraz $\mathrm{z}$ dodatkiem bioadiuwantu Stradale, skutecznie ograniczały występowanie szarej pleśni (Botrytis cinerea) i czerni krzyżowych (Alternaria spp.) na rzepaku ozimym. Niektórzy autorzy 
Tabela 5. Plon i masa 1000 nasion rzepaku ozimego w latach badań 2014-2015

Table 5. Yield and weight of 1000 seeds of winter oilseed rape in years 2014-2015

\begin{tabular}{|c|c|c|c|c|}
\hline \multirow[b]{2}{*}{$\begin{array}{l}\text { Kombinacja (dawka na } 1 \text { ha) } \\
\text { Treatment (dose per } 1 \text { ha) }\end{array}$} & \multicolumn{2}{|c|}{2014} & \multicolumn{2}{|c|}{2015} \\
\hline & $\begin{array}{c}\text { masa } \\
1000 \text { nasion } \\
\text { weight } \\
\text { of } 1000 \text { seed } \\
\text { [g] }\end{array}$ & $\begin{array}{l}\text { plon } \\
\text { yield } \\
\text { [t/ha] }\end{array}$ & $\begin{array}{c}\text { masa } \\
1000 \text { nasion } \\
\text { weight } \\
\text { of } 1000 \text { seed } \\
\text { [g] }\end{array}$ & $\begin{array}{l}\text { plon } \\
\text { yield } \\
\text { [t/ha] }\end{array}$ \\
\hline Kontrola - Untreated & 5,02 a & 3,00 a & 6,09 a & 3,86 a \\
\hline Caryx 240 SL (1,0 l) & 4,65 a & $3,03 \mathrm{ab}$ & 6,09 a & $4,15 b$ \\
\hline Caryx 240 SL (1,0 l) + bioadiuwant (100 g) & $4,91 \mathrm{a}$ & $3,44 \mathrm{~cd}$ & 6,28 a & 3,95 a \\
\hline Caryx 240 SL (0,75 l) + bioadiuwant (100 g) & 5,09 a & 3,3 abcd & $6,21 \mathrm{a}$ & $4,10 \mathrm{ab}$ \\
\hline Tebu 250 EW (1,0 l) & $5,27 \mathrm{a}$ & $3,47 \mathrm{~d}$ & $6,10 \mathrm{a}$ & 3,94 a \\
\hline Tebu 250 EW $(1,0$ l) + bioadiuwant (100 g) & 5,26 a & 3,41 bcd & 6,23 a & $3,99 a b$ \\
\hline Tebu 250 EW (0,75 l) + bioadiuwant (100 g) & 5,02 a & $3,06 \mathrm{abc}$ & $6,20 \mathrm{a}$ & $4,01 \mathrm{ab}$ \\
\hline
\end{tabular}

bioadiuwant - bioadjuvant

Wartości średnie oznaczone tą samą literą nie różnią się istotnie

Means followed by the same letter are not significantly different

z kolei nie odnotowali istotnego oddziaływania dodatku syntetycznych adiuwantów do fungicydów (m.in. z grupy triazoli), tłumacząc to wpływem innych czynników związanych z doborem adiuwantów, dawki, formulacji, techniki opryskiwania czy występujących warunków pogodowych (Karolewski i wsp. 2009; Ratajkiewicz i wsp. 2009). W wykonanych badaniach potwierdzono pozytywne działanie fungicydów $\mathrm{z}$ dodatkiem adiuwantu wielokomponentowego, zawierającego w swym składzie naturalne biosurfaktanty, które mogą wykazywać działanie wspomagające $\mathrm{W}$ walce $\mathrm{z}$ niektórymi drobnoustrojami (Deleu i Paquot 2004).

\section{Wnioski / Conclusions}

1. Pod wpływem wielokomponentowego bioadiuwantu Stradale obserwowano spadek napięcia powierzch- niowego cieczy użytkowej zawierającej fungicydy, jednak najczęściej miał on charakter nieistotny.

2. Wykonane oceny porażenia rzepaku ozimego przez patogeny (B. cinerea i Alternaria spp.) wykazały pozytywny wpływ dodatku bioadiuwantu na biologiczne działanie zastosowanych fungicydów.

3. Nie stwierdzono fitotoksycznego oddziaływania badanych środków zastosowanych pojedynczo oraz z dodatkiem bioadiuwantu na rośliny rzepaku ozimego odmiany Bogart.

4. Masa tysiąca nasion pomiędzy kontrolą a badanymi obiektami nie różniła się w sposób istotny.

5. Istotnie wyższy plon nasion rzepaku ozimego na obiektach chronionych pełną dawką fungicydów $\mathrm{z}$ dodatkiem bioadiuwantu Stradale $\mathrm{W}$ porównaniu $\mathrm{z}$ kontrolą stwierdzono jedynie $\mathrm{w}$ pierwszym roku badań, co prawdopodobnie miało związek z silniejszym, w porównaniu do drugiego roku badań, porażeniem roślin rzepaku przez grzyby.

\section{Literatura / References}

Chappell R.A. 1995. Water-base film forming composition for inhibiting growth of mold and fungus. Patent amerykański US 5415887 A.

Deleu M., Paquot M. 2004. From renewable vegetables resources to micro-organisms: new trends in surfactants. C.R. Chimie 7 (6): 641-646.

Eratte D., McKnight S., Gengenbach T.R., Dowling K., Barrow C.J., Adhikari B.P. 2015. Co-encapsulation and characterisation of omega-3 fatty acids and probiotic bacteria in whey protein isolate-gum Arabic complex coacervates. Journal of Functional Foods 19, Part B: 882-892.

Karolewski Z., Wachowiak M., Ratajkiewicz H., Kierzek R. 2009. Effect of adjuvants, spray volume and nozzle type on metconazole activity against Leptosphaeria biglobosa and L. maculans during late spring treatments in winter oilseed rape. Journal of Plant Protection Research 49 (1): 113-117.

Korbas M., Jajor E., Danielewicz J., Sobiech Ł., Perek A., Horoszkiewicz-Janka J. 2016. Skuteczność wybranych fungicydów w zależności od właściwości fizycznych roztworu. [Effectiveness of selected fungicides as function of physical properties of their solution]. Przemysł Chemiczny 95 (7): 1395-1397.

Kurtz D.A., Hassett K. 1988. Pesticide-polymer research: A review of 1976-87. p. 17-43. In: “Applied Bioactive Polymeric Materials” (C.G. Gebelin, C.E. Carraher, V.R. Foster, eds.). Plenum Press, New York, 334 pp.

Lima T.M., Procopio L.C., Brandao F.D., Leao B.A., Totola M.R., Borges A.C. 2011. Evaluation of bacterial surfactant toxicity towards petroleum degrading microorganisms. Bioresource Technology 102 (3): 2957-2964.

Mrówczyński M., Pruszyński S. (red.). 2008. Integrowana produkcja rzepaku ozimego i jarego. Instytut Ochrony Roślin, Poznań, 107 ss. Paraszkiewicz K., Długoński J. 2003. Biosurfaktanty drobnoustrojowe - synteza i zastosowanie. Biotechnologia 4 (63): 82-91.

Pattanathu K.S.M., Gakpe E. 2008. Production, characterizations and applications of biosurfactants - review. Biotechnology 7 (2): $360-370$. 
Ratajkiewicz H., Kierzek R., Karolewski Z., Wachowiak M. 2009. The effect of adjuvants, spray volume and nozzle type on azoxystrobin efficacy against Leptosphaeria maculans and L. biglobosa on winter oilseed rape. Journal of Plant Protection Research 49 (4): 440-445.

Sachdev D.P., Cameotra S.S. 2013. Biosurfactants in agriculture. Applied Microbiology and Biotechnology 97 (3): $1005-1016$.

Sawinska Z., Sobiech Ł., Danielewicz J., Perek A., Horoszkiewicz-Janka J., Skrzypczak G. 2016. Wpływ związków powierzchniowo czynnych na skuteczność fungicydów z grupy triazoli. [The impact of surfactants on efficiency of the triazole fungicides]. Przemysł Chemiczny 95 (6): 1141-1143.

Scott M.J., Jones M.N. 2000. The biodegradation of surfactants in the environment. Biochimica et Biophysica Acta 1508 (1-2): $235-251$.

Sha R., Jiang L., Meng Q., Zhang G., Song Z. 2012. Producing cell-free culture broth of rhamnolipids as a cost-effective fungicide against plant pathogens. Journal of Basic Microbiology 52: 458-466.

Singh A., Van Hamme J.D., Ward O.P. 2007. Surfactants in microbiology and biotechnology: Part 2. Application aspects. Biotechnology Advances 25 (1): 99-121.

Zhang F., Gu W., Xu P., Tang S., Xie K., Huang X., Huang Q. 2011. Effects of alkyl polyglycoside (APG) on composting of agricultural wastes. Waste Management 31 (6): 1333-1338. 